\title{
Pengaruh Peran Orang Tua terhadap Pengetahuan Remaja tentang Kesehatan Reproduksi
}

\section{Influence The Role of Parents of Adolescent about Reproductive Health Knowledge}

\section{Yulrina Ardhiyanti}

\section{Program Studi Kebidanan Sekolah Tinggi Ilmu Kesehatan Hang Tuah Pekanbaru}

\begin{abstract}
ABSTRAK
Pengetahuan remaja mengenai kesehatan reproduksi di kota Pekanbaru cukup rendah yang dibuktikan dengan adanya data yang diperoleh dari PKBI Kota Pekanbaru mengenai kasus aborsi di kalangan remaja sebanyak 21,2 \%. Kasus HIV/AIDS, Kota Pekanbaru merupakan kasus AIDS tertinggi dan kasus HIV pada kelompok remaja merupakan urutan ketiga tertinggi. Penelitian ini dilakukan untuk mengetahui faktor-faktor yang berhubungan dengan pengetahuan remaja tentang kesehatan reproduksi di SMA Negeri Se-Kota Pekanbaru tahun 2013. Penelitian ini merupakan penelitian kuantitatif dengan desain penelitian cross sectional study. Jumlah sampel 250 orang remaja SMA Negeri Se-Kota Pekanbaru. Prosedur pengambilan sampel dengan cara systematic random sampling, pengambilan data menggunakan kuesioner dan analisis data dilakukan secara univariat, bivariat dengan uji chi-square, multivariat dengan uji regresi logistik ganda. Hasil penelitian diperoleh sebagian besar pengetahuan remaja tentang kesehatan reproduksi kurang baik sebanyak 161 orang $(64,4 \%)$, variabel yang berhubungan dengan pengetahuan remaja tentang kesehatan reproduksi adalah peran orang tua (OR : 1,982; 95 \% CI : 1,127-3,487), variabel yang tidak berhubungan dengan pengetahuan remaja tentang kesehatan reproduksi adalah pengaruh teman sebaya, peran guru, peran petugas kesehatan dan akses media massa. Sebaiknya diupayakan agar orang tua meningkatkan pengetahuan tentang kesehatan reproduksi, menjalin kedekatan dengan anak dan menentukan kapan waktu yang tepat untuk memberikan pengetahuan tentang kesehatan reproduksi sehingga informasi yang diperoleh merupakan yang pertama sebelum anak mendapatkannya dari yang lain.
\end{abstract}

Kata Kunci : Peran orang tua, Pengetahuan Remaja tentang Kesehatan Reproduksi, Kota Pekanbaru

\section{ABSTRACT}

Knowledge of adolescents on reproductive health in the city of Pekanbaru is quite low as evidenced by the data obtained from the Pekanbaru city PKBI abortions among teenagers as much as 21.2\%. Cases of HIV/AIDS, Pekanbaru is the highest AIDS case and HIV cases in the group is the third highest teen. This study was conducted to determine the factors associated with adolescents about reproductive health knowledge in all high school in Pekanbaru in 2013. This study is a quantitative research with cross sectional research design study. Number of samples is 250 teens high school in Pekanbaru. The sampling procedure by systematic random sampling, data collection and analysis of data using questionnaires univariate, bivariate chi-square test, multivariate multiple logistic regression. The results obtained most of the knowledge of adolescents about reproductive health is not good as much as 161 people (64.4\%), variables related to the knowledge of adolescents about reproductive health is the role of parents (OR : 1.982; 95\% CI:1.127-3.487), the variable which is not related to knowledge of adolescents about reproductive health is the influence of peers and teachers who become confounding variables with other variables. Parents should be pursued in order to increase knowledge about reproductive health, attachment to the child and determine when it is appropriate to provide knowledge about reproductive health so that the information obtained is the first before the child got it from the others.

Keywords : Role of parents, Knowledge of Adolescent Reproductive Health, Pekanbaru City

\section{PENDAHULUAN}

Pengetahuan remaja tentang kesehatan reproduksi adalah segala informasi yang diperoleh remaja yang berkaitan dengan kesehatan reproduksi. Pengetahuan remaja tentang kesehatan reproduksi sangat penting untuk menghadapi perubahan dan permasalahan pada masa remaja. Remaja rentan terhadap permasalahan kesehatan reproduksi, seperti : masa pubertas, Penyakit Menular Seksual (PMS) dan
Human Immunodefiency Virus (HIV) / Acquired Immunodeficiency Syndrome (AIDS), Kehamilan Tidak Diinginkan (KTD) dan aborsi (Puslibang \& BKKBN, 2012).

Di dunia, sebanyak $11 \%$ dari kehamilan setiap tahun terjadi di kalangan remaja (UNICEF, 2012). Di Amerika Latin dan Karibia sebanyak 35-52 \% remaja mengalami kehamilan yang tidak direncanakan 
dikarenakan kurangnya pengetahuan tentang kehamilan dan mestruasi (Aine \& Maddaleno, 2003)

Pengetahuan remaja di dunia tentang kesehatan reproduksi masih rendah, hal ini dibuktikan dengan penelitian yang dilakukan di Brazil bahwa pengetahuan tentang pubertas terhadap 399 remaja, sebanyak 57,6 \% berpengetahuan rendah (Gomes, 2002). Penelitian mengenai pengetahuan remaja tentang PMS dan HIV/AIDS di Bangladesh menunjukkan bahwa 54,8 \% remaja tidak mengetahui tentang AIDS, 32,9 \% remaja tidak mengetahui tentang syphilis, $27,1 \%$ remaja tidak mengetahui ulcus genital, $22 \%$ remaja tidak mengetahui tentang gonorhoe, $0,6 \%$ remaja tidak mengetahui tentang chlamidia dan $0,1 \%$ remaja tidak mengetahui tentang trichomonas (Rahman et all, 2009).

Survei Demografi dan Kesehatan Indonesia Remaja (SDKI-R) tahun 2007, pengetahuan remaja umur 15-24 tahun tentang kesehatan reproduksi masih rendah. Sebanyak 13,3 \% remaja perempuan tidak mengetahui perubahan fisik pada anak perempuan saat pubertas dan $21 \%$ remaja perempuan tidak mengetahui sama sekali perubahan yang terjadi pada remaja laki-laki saat pubertas. Hampir separuh (47,9 $\%$ ) remaja perempuan tidak mengetahui kapan seorang perempuan mengalami masa subur. Pengetahuan remaja tentang cara paling penting untuk menghindari infeksi HIV juga masih terbatas, hanya 40,8 \% mengetahui informasi tentang HIV/AIDS, informasi tentang kondom sebesar $29,6 \%$ dan infeksi menular seksual (IMS) sebesar 18,4 \% (Puslitbang Kependudukan-BKKBN, 2011).

Banyak remaja tidak memiliki pengetahuan yang akurat tentang kesehatan reproduksi. Pengetahuan remaja tentang kesehatan reproduksi dipengaruhi oleh beberapa faktor. Penelitian yang dilakukan Laksmiwati (2011), pengetahuan remaja tentang kesehatan reproduksi dipengaruhi oleh faktor di dalam individu dan faktor di luar individu. Faktor di dalam individu adalah sikap permisif dari individu yang bersangkutan. Faktor di luar individu adalah faktor lingkungan dimana remaja tersebut berada yang terdiri dari faktor orang tua dan teman sebaya. Penelitian yang dilakukan Kurniawan (2008), pengetahuan remaja tentang kesehatan reproduksi dipengaruhi oleh sikap, peran orang tua serta peran guru. Penelitian yang dilakukan Putriani (2010), pengetahuan remaja dipengaruhi oleh orang tua, teman dan media massa.

Wawancara yang dilakukan terhadap salah satu pengurus Perkumpulan Keluarga Berencana Indonesia (PKBI) Kota Pekanbaru mengatakan bahwa pergaulan bebas dikalangan remaja khususnya Pekanbaru telah mencapai titik kekhawatiran yang cukup parah terutama perilaku seks bebas. Hal itu dibuktikan dengan aborsi yang dilakukan di kalangan remaja di Pekanbaru sebanyak 21,2\%. Kasus HIV/AIDS, kota
Pekanbaru merupakan kasus AIDS tertinggi dan kasus HIV pada kelompok remaja merupakan urutan ketiga tertinggi berdasarkan kelompok umur (Profil Kesehatan Propinsi Riau, 2010). Survei yang telah dilakukan pada beberapa Sekolah Menengah Atas (SMA) Negeri yang ada di Kota Pekanbaru, program Pelayanan Kesehatan Peduli Remaja (PKPR) yang dilaksanakan dalam memberikan informasi kesehatan reproduksi masih belum menjangkau seluruhnya. Sehingga masih banyak pelajar yang belum mendapatkan informasi mengenai kesehatan reproduksi.

\section{METODE}

Jenis penelitian ini adalah Kuantitatif Analitik Observasional dengan desain penelitian Cross Sectional yang dilaksanakan mulai bulan Juni sampai dengan bulan Juli 2013 di SMA Negeri Se-Kota Pekanbaru. Besar sampel adalah 250 orang remaja SMA Negeri Se-Kota Pekanbaru kelas X dan XI tahun ajaran 2012/2013 dengan mempertimbangkan $\alpha=$ $0,05, \beta=90 \%$ dan proporsi $=0,65$ yang dihitung menggunakan Rumus Lameshow One Sample Hypothesis One Side. Prosedur pengambilan sampel dilakukan secara systematic random sampling. Jenis data yang dikumpulkan adalah data primer yang dilakukan dengan wawancara terstruktur dengan menggunakana instrumen kuisioner peran orang tua dilihat dari ada atau tidaknya peran orang tua remaja dalam memberikan informasi mengenai kesehatan reproduksi. Analisis bivariat dilakukan dengan uji Chi-Square dan uji Regresi Logistik Ganda dengan Model Prediksi untuk Analisis Multivariat.

\section{HASIL}

Hasil analisis univariat didapatkan sebagian besar pengetahuan remaja tentang kesehatan reproduksi kurang baik yaitu 161 orang $(64,4 \%)$, remaja yang orang tuanya tidak berperan sebanyak 153 orang $(61,2 \%)$, remaja yang tidak dipengaruhi teman sebaya sebanyak 137 orang $(54,8 \%)$, remaja yang gurunya tidak berperan sebanyak 131 orang $(52,4 \%)$, remaja yang petugas kesehatannya tidak berperan sebanyak 135 orang $(54,0 \%)$ dan sebagian besar remaja mengakses media massa yaitu 199 orang $(79,6$ $\%)$.

Hasil uji bivariat terhadap 5 variabel, terdapat 4 variabel yang mempunyai hubungan signifikan dengan pengetahuan remaja tentang kesehatan reproduksi yaitu Peran Orang tua (pvalue $=0,001$ ), Pengaruh Teman Sebaya (pvalue $=0,014)$, Peran Guru (pvalue $=$ 0,007 ), Peran Petugas Kesehatan (pvalue $=0,011$ ). Sedangkan variabel Akses Media Massa tidak bermakna secara statistik (lihat tabel 1).

Hasil analisis multivariat dapat disimpulkan bahwa variabel yang berhubungan secara bermakna dengan pengetahuan remaja tentang kesehatan reproduksi adalah Peran Orang tua dengan nilai $\mathrm{OR}=$ 
1,982 artinya remaja yang orang tuanya tidak berperan berisiko 2 kali memiliki pengetahuan tentang kesehatan reproduksi yang kurang baik dibanding remaja yang orang tuanya berperan (lihat tabel 2).
Variabel confounding yaitu variabel pengaruh teman sebaya confounding dengan variabel peran guru dan variabel peran guru confounding dengan variabel pengaruh teman sebaya (lihat tabel 2).

Tabel 1

Faktor-faktor yang Berhubungan dengan Pengetahuan Remaja tentang Kesehatan Reproduksi di SMA Negeri SeKota Pekanbaru Tahun 2013

\begin{tabular}{|c|c|c|c|c|c|c|c|}
\hline \multirow[t]{3}{*}{ Variabel } & \multicolumn{5}{|c|}{$\begin{array}{c}\text { Pengetahuan remaja tentang kesehatan } \\
\text { reproduksi }\end{array}$} & \multirow[t]{3}{*}{$\underset{\text { Value }}{p}$} & \multirow[t]{3}{*}{$\begin{array}{l}\text { OR (95\% } \\
\text { CI) }\end{array}$} \\
\hline & \multicolumn{2}{|c|}{ Kurang baik } & \multicolumn{2}{|c|}{ Baik } & \multirow{2}{*}{$\begin{array}{r}\text { Total } \\
\text { n (\%) }\end{array}$} & & \\
\hline & $\mathbf{n}$ & $\%$ & $\mathbf{n}$ & $\%$ & & & \\
\hline \multicolumn{8}{|l|}{ Peran orang tua } \\
\hline Tidak berperan & 111 & 72,5 & 42 & 27,5 & $153(100)$ & \multirow[t]{3}{*}{0,001} & \multirow{3}{*}{$\begin{array}{c}2,484(1,457- \\
4,235)\end{array}$} \\
\hline Berperan & 50 & 51,5 & 47 & 48,5 & $97(100)$ & & \\
\hline Total & 161 & 64,4 & 89 & 35,6 & $250(100)$ & & \\
\hline \multicolumn{8}{|c|}{ Pengaruh teman sebaya } \\
\hline Tidak berpengaruh & 98 & 71,5 & 39 & 28,5 & $137(100)$ & \multirow[t]{3}{*}{0,014} & \multirow{3}{*}{$\begin{array}{c}1,994(1,180- \\
3,371)\end{array}$} \\
\hline Berpengaruh & 63 & 55,8 & 50 & 44,2 & $113(100)$ & & \\
\hline Total & 161 & 64,4 & 89 & 35,6 & $250(100)$ & & \\
\hline \multicolumn{8}{|l|}{ Peran guru } \\
\hline Tidak berperan & 95 & 72,5 & 36 & 27,5 & $131(100)$ & \multirow[t]{3}{*}{0,007} & \multirow{3}{*}{$\begin{array}{c}2,119(1,251- \\
3,590)\end{array}$} \\
\hline Berperan & 66 & 55,5 & 53 & 44,5 & $119(100)$ & & \\
\hline Total & 161 & 64,4 & 89 & 35,6 & $250(100)$ & & \\
\hline \multicolumn{8}{|c|}{ Peran petugas kesehatan } \\
\hline Tidak berperan & 97 & 71,9 & 38 & 28,1 & $135(100)$ & \multirow[t]{3}{*}{0,011} & \multirow{3}{*}{$\begin{array}{c}2,034(1,203- \\
3,440)\end{array}$} \\
\hline Berperan & 64 & 55,7 & 51 & 44,3 & $115(100)$ & & \\
\hline Total & 161 & 64,4 & 89 & 35,6 & $250(100)$ & & \\
\hline \multicolumn{8}{|l|}{ Akses media massa } \\
\hline Tidak mengakses & 38 & 74,5 & 13 & 25,5 & $51(100)$ & \multirow[t]{3}{*}{0,127} & \multirow{3}{*}{$\begin{array}{c}1,806(0,904 \\
3,607)\end{array}$} \\
\hline Mengakses & 123 & 61,8 & 76 & 38,2 & $199(100)$ & & \\
\hline Total & 161 & 64,4 & 89 & 35,6 & $250(100)$ & & \\
\hline
\end{tabular}

Tabel 2.

Permodelan Multivariat Tahap Akhir

\begin{tabular}{lcccc}
\hline Variabel & $\boldsymbol{p}$ & $\mathbf{O R}$ & $\mathbf{( 9 5} \% \mathbf{C I})$ \\
\cline { 3 - 5 } & value & & \multicolumn{2}{c}{} \\
\hline Peran orang tua & 0,018 & 1,982 & 1,127 & 3,487 \\
\hline $\begin{array}{l}\text { Pengaruh teman } \\
\text { sebaya }\end{array}$ & 0,151 & 1,507 & 0,861 & 2,638 \\
\hline Peran guru & 0,092 & 1,621 & 0,924 & 2,842 \\
\hline
\end{tabular}

\section{PEMBAHASAN}

Faktor yang Berhubungan dengan Pengetahuan Remaja tentang Kesehatan Reproduksi di SMA Negeri Se-Kota Pekanbaru

\section{Peran Orang Tua}

Remaja yang orang tuanya tidak berperan berisiko 2 kali memiliki pengetahuan tentang kesehatan reproduksi kurang baik dibanding remaja yang orang tuanya berperan $(95 \% \mathrm{CI}=1,127-3,487)$. Orang tua mempunyai peranan yang penting dalam menyampaikan informasi tentang seks dan seksualitas, karena orang tua adalah sumber pertama dimana seorang anak belajar dan dibimbing mengenal seks sampai mereka menjadi remaja. Orang tua perlu membekali diri dengan pengetahuan mengenai hal-hal yang berhubungan dengan perkembangan seksualitas remaja. Pengetahuan dan sikap orang tua mengenai seksualitas dan kesehatan reproduksi sangat berpengaruh terhadap pengetahuan dan sikap anak /remaja terhadap masalah tersebut (BKKBN, 2008).

Penelitian ini sesuai dengan penelitian yang dilakukan oleh Cahyo (2008), Anggrainy (2010), Yazici, et all (2011) dan Indarwati (2013), bahwa peran orang tua ada hubungan dengan pengetahuan remaja tentang kesehatan reproduksi. Untuk itu sebaiknya diupayakan agar orang tua meningkatkan pengetahuan tentang kesehatan reproduksi, menjalin kedekatan dengan anak dan menentukan kapan waktu yang tepat untuk memberikan pengetahuan tentang kesehatan reproduksi sehingga informasi yang diperoleh merupakan yang pertama sebelum anak mendapatkannya dari yang lain.

\section{Faktor yang Tidak Berhubungan dengan Pengetahuan Remaja tentang Kesehatan Reproduksi di SMA Negeri Se-Kota Pekanbaru}

Pengaruh Teman Sebaya

Analisis multivariat, menunjukkan bahwa tidak ada hubungan pengaruh teman sebaya dengan pengetahuan remaja tentang kesehatan reproduksi dalam penelitian ini, untuk penelitian lebih lanjut perlu 
pemilihan sampel pada remaja yang memiliki hubungan erat dengan teman sebaya yaitu remaja yang tinggal di asrama.

\section{Peran Guru}

Analisis multivariat, menunjukkan bahwa tidak ada hubungan peran guru dengan pengetahuan remaja tentang kesehatan reproduksi dalam penelitian ini, untuk penelitian lebih lanjut perlu pemilihan sampel pada siswa siswi yang telah mendapatkan materi mengenai kesehatan reproduksi.

\section{Peran Petugas Kesehatan}

Analisis multivariat, menunjukkan bahwa tidak ada hubungan peran petugas kesehatan dengan pengetahuan remaja tentang kesehatan reproduksi dalam penelitian ini, untuk penelitian lebih lanjut perlu dilakukan pada petugas kesehatan yang berperan. Dalam hal ini diperlukan evaluasi pelaksanaan program puskesmas khususnya pada petugas kesehatan yang bertanggung jawab dengan program PKPR.

\section{Akses Media Massa}

Analisis multivariat, menunjukkan bahwa tidak ada hubungan akses media massa dengan pengetahuan remaja tentang kesehatan reproduksi dalam penelitian ini, untuk penelitian lebih lanjut perlu ditentukan media massa yang paling berpengaruh memberikan informasi positif mengenai kesehatan reproduksi, misalnya: majalah kesehatan.

\section{KESIMPULAN}

Dari hasil analisis multivariat, variabel yang berhubungan secara signifikan adalah variabel peran orang tua. Nilai OR dari variabel peran orang tua adalah 1,982 artinya remaja yang orang tuanya tidak berperan berisiko 2 kali memiliki pengetahuan tentang kesehatan reproduksi yang kurang baik dibanding remaja yang orang tuanya berperan.

\section{SARAN}

Diharapkan agar orang tua meningkatkan pengetahuan tentang kesehatan reproduksi. Upaya yang dapat dilakukan orang tua dalam meningkatkan perannya yaitu dengan memperluas wawasan pengetahuan mengenai kesehatan reproduksi. Hal ini bisa dilakukan dengan mengikuti kegiatan penyuluhan, membaca majalah yang berkaitan dengan kesehatan reproduksi ataupun menonton televisi.

Selain itu, kehidupan keluarga yang harmonis mutlak diperlukan agar kedekatan antara orang tua dan anak dapat terjalin. Hal ini sangat diperlukan agar orang tua tidak merasa tabu memberikan informasi mengenai kesehatan reproduksi kepada anaknya. Orang tua harus tahu kapan waktu yang tepat untuk membekali anaknya mengenai pengetahuan kesehatan reproduksi. Informasi akan sangat baik diberikan dengan adanya peran kedua belah pihak yaitu ayah dan ibu. Ibu memberikan informasi mengenai kesehatan reproduksi kepada anak perempuan dan ayah memberikan informasi mengenai kesehatan reproduksi kepada anak laki-laki sehingga diharapkan anak telah mempunyai informasi yang cukup dari orang tua sebelum mendapatkannya dari luar.

\section{UCAPAN TERIMA KASIH}

Ucapan terima kasih ditujukan kepada dr. H. Zainal Abidin, MPH selaku Ketua STIKes dan Prof. DR. dr. Buchari Lapau, MPH selaku Ketua Prodi Magister IKM STIKes Hang Tuah Pekanbaru, DR. dr. H. Toha Muhaimin, MSc dan dr. Hj. Fachriani Putri, MKM selaku Pembimbing dan drg. Oktavia Dewi, M.Kes dan Ns. Ezalina, S.Kep, M.Kes selaku Penguji serta Kepala Sekolah SMA Negeri Se-Kota Pekanbaru tempat penelitian ini dilakukan.

\section{DAFTAR PUSTAKA}

Aine, J.S., \& Maddaleno, M. (2003). Sexual health and development of adolescents and youth in the Americas, (http://www.hawaii.edu/hivandaids/ Sexual Health and Development of Adolesc ents and Youth in the Americas.pdf, diakses 04 Mei 2013).

Anggrainy, M.L. (2010). Pengetahuan remaja tentang kesehatan reproduksi di SMA Muhammadiyah Pekanbaru Tahun 2010. Skripsi tidak diterbitkan. Program Studi Ilmu Kesehatan Masyarakat STIKes Hang Tuah Pekanbaru, Pekanbaru.

Cahyo, dkk. (2008). Faktor-faktor yang mempengaruhi praktik kesehatan reproduksi remaja di SMA Negeri 1 Purbalingga Kabupaten Purbalingga, (http://ejournal s1.undip.ac.id, diakses 17 Maret 2013).

Gomes, et all. (2002). Adolescent' knowledge about adolescence, puberty and sexuality, (Online), Vol. 78, No. 4, (http://www.jped.com.br/conteudo/02-78-04301/ing.pdf, diakses 02 Mei 2013).

Indarwati, S. (2013). Peran orang tua dan pengetahuan remaja tentang pubertas di salah satu SMP Negeri Boyolali, (Online), Vol. 10, No. 1, (http://www.jurnal.stikes-aisyiyah.ac.id, diakses 07 Juli 2013).

Kurniawan, T.P. (2008). Faktor-faktor yang berpengaruh terhadap praktek kesehatan reproduksi remaja di SMA Negeri 1 Purbalingga Kabupaten Purbalingga, (http://eprints.undip.ac.id/18028/1/TRI PRAP TO_KURNIAWAN.pdf, diakses 18 Maret 2013). 
Laksmiwati, A. (2011). Transformasi sosial dan perilaku reproduksi remaja, (ojs.unud.ac.id/index.php/srikandi/article/dow nload/2756/1949, diakses 08 Maret 2013).

Profil Kesehatan Propinsi Riau. (2010).

Putriani, N. (2010). Faktor-faktor yang mempengaruhi pengetahuan remaja tentang kesehatan reproduksi di SMA Negeri 1 Mojogedang, (http://eprints.undip.ac.id/10681/1/Abstrak.pdf , diakses 08 Maret 2013).

Puslitbang Kependudukan-BKKBN. (2011). Kajian profil penduduk remaja (10-24 tahun) : Ada apa dengan Remaja? (http://www.bkkbn.go.id/litbang/pusdu/Hasil\% 20Penelitian/Karakteristik\%20Demografis/201 1/Kajian\%20Profil\%20Penduduk\%20Remaja $\% 20 \% 2810 \% 20-\% 2024 \% 20$ tahun $\% 29$.pdf, diakses 18 Maret 2013).

Pulibang \& BKKBN. (2012). Pengaruh Sumber Informasi Terhadap Pengetahuan Remaja tentang Triad KRR dan Penyiapan Kehidupan Berkeluarga bagi Remaja (PKBR), (http://www.bkkbn.go.id/litbang/pusna/Hasil\% 20Penelitian/Analisis\%20Lanjut/Tahun $\% 2020$ 12/Pengaruh\%20Sumber\%20Informasi\%20Te rhadap $\% 20$ Pengetahuan $\% 20$ Remaja $\% 20$ Tenta ng\%20TRIAD $\% 20 \% 20$ KRR $\% 20$ dan $\% 20$ Peny iapan\%20Kehidupan\%20Berkeluarga\%20bagi \%20Remaja.pdf, diakses 01 Mei 2013).

Rahman, M., Kabir, M. \& Shahidullah, M. (2009). Adolescent knowledge and awareness about AIDS/HIV and factors affecting them in Bangladesh,(http://www.ayubmed.edu.pk/JA MC/PAST/21-3/Mizan.pdf, diakses 02 Mei 2013).

UNICEF. (2012). Progress for children, a report card on adolescents, (http://www.unicef.org/media/files/PFC2012 A report card on adolescents.pdf, diakses 04 Mei 2013).

Yazici, S., Dolgun, G., Ozturk, Y. \& Yilmaz, F. The Level of Knowledge and Behavior of Adolescent Male and Female Students in Turkey on the Matter of Reproductive Health, (Online). DOI 10.1007/s11195-011-9204-x, (http://web.ebscohost.com/ehost/pdfviewer/pdf viewer?vid=10\&sid=41482429-a14c-43ad $8680 \mathrm{~b} 51$ bcdde611d\%40sessionmgr11\&hid $=12$ 7, diakses 24 Juni 2013). 